\title{
Persevering with Geography
}

\section{John Morgan}

University of Auckland. Faculty of Education and Social Work, School of Curriculum and Pedagogy

john.morgan@auckland.ac.nz

Reception: March 2017

Acceptance: June 2017

\begin{abstract}
This paper offers an analysis of the current state of geography education, based on the author's experience as a geography teacher, teacher educator and researcher. It starts from a concern that recent discussions of 'teacher quality' have tended to downplay (or at least simply assume) the importance of subject and disciplinary knowledge in favour of more generic teaching skills. This raises the question of why anyone would persevere as a geography teacher? Using the example of the UK's decision to leave the European Union, the paper suggests the depth and knowledge of geographical concepts that a teacher would need to teach this topic well, before going on to explain how the trajectory of geography teacher education over the past three decades has moved away from a focus on geographical content and the complexities of knowledge. The final section of the paper refers to some recent developments linked to the work of 'social realist' perspectives, and suggests what 'bringing knowledge back in' might entail in teacher education programmes.
\end{abstract}

Keywords: geography teacher education; political geography; Brexit; social realism; knowledge

\section{Resum. Perseverant amb la geografia}

Aquest article analitza l'estat actual de l'ensenyament de la geografia, i ho fa a partir de l'experiència de l'autor com a professor d'aquesta matèria, com a formador de futurs professors de geografia i com a investigador d'aquest camp científic. L'escrit mostra la preocupació envers els darrers debats sobre la qualitat del professorat, que incideixen en la manera com cal ensenyar i no pas a tenir un bon coneixement disciplinari. Davant d'aquesta tendència, ens hem de preguntar què és el que provoca que un professor de geografia perseveri per voler ser-ho. Perquè, per abordar temes geogràfics complexos amb solvència, com ara el Brèxit, cal un coneixement geogràfic conceptual específic i d'una certa profunditat. En canvi, l'anàlisi de la formació inicial que ha rebut el professorat al llarg de les darreres tres dècades mostra un abandonament progressiu de l'atenció vers el contingut acadèmic i les complexitats del coneixement. L'article acaba amb una reflexió sobre les aportacions del realisme social i sobre què pot significar retornar el coneixement disciplinari als programes de formació del professorat.

Paraules clau: formació del professorat en geografia; geografia política; Brèxit; realisme social; coneixement 


\section{Resumen. Perseverando con la geografía}

Este artículo analiza el estado actual de la enseñanza de la geografía y, para ello, se basa en la experiencia del autor como profesor de esta materia, como formador de futuros profesores de geografía y como investigador en este campo científico. El texto parte de la preocupación acerca de los debates actuales sobre calidad del profesorado que priman las habilidades de enseñanza de los docentes por encima del conocimiento disciplinario. Ante esta tendencia, nos cabe preguntar qué provoca que un profesor de geografía persevere en la voluntad de serlo. Porque, para explicar temas geográficos complejos de forma solvente, como por ejemplo la decisión del Reino Unido de abandonar la Unión Europea, el profesorado necesita tener un conocimiento geográfico conceptual profundo. En cambio, el análisis de la formación del profesorado de geografía en las tres últimas décadas muestra que esta ha ido abandonando progresivamente la atención sobre el contenido académico y las complejidades del conocimiento. El texto acaba con una reflexión sobre las aportaciones del realismo social y sobre qué puede significar traer de vuelta el conocimiento disciplinario a los programas de formación del profesorado.

Palabras clave: formación del profesorado en geografía; geografía política; brexit; realismo social; conocimiento

\section{Résumé. En persévérant avec la géographie}

Cet article propose une analyse de l'état actuel de l'éducation en géographie, à partir de l'expérience de l'auteur en tant que professeur de géographie, formateur de formateurs et chercheur. Cela part d'une préoccupation selon laquelle les discussions récentes sur la "qualité des enseignants» ont tendance à minimiser (ou tout simplement à supposer) l'importance des connaissances disciplinaires en faveur de compétences d'enseignement plus génériques. Ceci soulève la question de savoir pourquoi un professeur de géographie persévère en tant que tel. En utilisant l'exemple de la décision du Royaume-Uni de quitter l'Union européenne, le document évoque la profondeur et la connaissance des concepts géographiques dont l'enseignant aurait besoin pour bien enseigner cette matière. L'article explique ensuite comment au cours des trois dernières décennies la trajectoire de formation des enseignants en géographie s'est éloignée de l'accent mis sur le contenu géographique et la complexité de la connaissance. La dernière section de l'article se réfere à certains développements récents liés au travail de perspectives «réalistes sociales», et suggère ce que «récupérer les connaissances disciplinaires » pourrait impliquer dans les programmes de formation des enseignants.

Mots-clés: formation des enseignants en géographie; Géographie politique; Brexit; réalisme social; connaissance

\section{Summary}

\section{Introduction}

2. Do we really need geography teachers?

3. Thinking geographically about Brexit

4. Towards a theory of geography teaching
5. The right kind of geography?

6. Conclusion

Bibliographical references 


\section{Introduction}

The title of this article refers to a comment by the late cultural theorist Stuart Hall. Hall was recalling his early experience of teaching geography in a secondary modern school in Brixton, London. As a non-specialist teacher of geography, he feared that he would one day get the directions of the trade winds confused. In the end, Hall (2008:12) recalls, 'I persevered with my geography'. Hall's comments raise an important question to anyone teaching geography (or contemplating teaching geography) in schools today: why is it worth 'persevering with geography'? This article focuses on what it means to teach geography in schools in the early years of the $21^{\text {st }}$ century. I am concerned with teacher education and teacher preparation. I want to argue that current arguments about the nature of teacher education are based on a narrow view of the purpose of school subjects in the curriculum, and that dominant approaches to geography teacher education fail to answer the question of how we should prepare teachers for an extended life in schools. In what follows I attempt to explain how this situation came about and how it might be remedied. ${ }^{2}$

The first section of this paper discusses recent attempts to try to place a quantifiable value on the role of subject specialist teaching in schools. That we should be even having this discussion says something about the nature of educational debate at this time, so I want to try to situate these arguments in a slightly broader context than is usual. The second section seeks to show the absurdity of these narrow discussions when faced with the actuality of an event that even the most narrow-minded educational 'mind-set' would surely admit is worthy of teaching in schools - that of 'Brexit' or the United Kingdom's historic decision to leave the European Union. In this section I suggest just what it is that a 'clever' geography teacher would need to be able to know and understand in order to teach about this topic. The notion that a teacher operates as a public intellectual, as a scholarly figure who is seeking to involve and engage pupils in an educationally worthwhile activity stems from earlier models of teaching and professionalism, but one that has gradually lost its status and is rapidly receding from the collective memory. Some of the reasons for this are discussed in section three of the paper which takes the form of a brief history of geography teacher education. The article concludes with a discussion of how geography teacher education would benefit from a renewed focus on developing teachers' capacity to deal with the complexities of geographical knowledge and theory. Only then will it be possible to prepare teachers who

1. It is ironic, then, that Hall's writing in Cultural Studies would later be picked up and developed by human geographers, especially his collaboration with Doreen Massey in the journal Soundings. The phrase I persevered with my geography is discussed by David Bell in an article exploring the relationship between cultural studies and geography (Bell, 2016)

2. The paper draws upon literature in Anglo-American Geography. It reflects the experience of the author who has worked as a geography educator in Britain and Australasia. It is hoped that the argument and the examples used will be familiar to readers, and that it may prompt comparisons with the situation in other countries. 
have the knowledge and skill to teach about an event such as Brexit in all its complexity and importance.

\section{Do we really need geography teachers?}

In 2016, the Department for Education in England published a research paper on the theme of 'Specialist' and 'non-specialist' teaching in England: Extent and impact on pupil outcomes. (DfE, 2016: 7). The research paper's purpose was to present evidence about the extent to which subject expertise has an impact of students' educational outcomes. The report sought to summarise 'existing evidence and provides new analysis on the extent and impact of 'specialist' and 'non-specialist' teaching in England. It has been produced to inform public debate and to feed into further policy making related to subject specialism'.

Leaving aside for the moment the question of whether there is actually a public debate about this issue, the research paper notes that most secondary teaching in England is conducted by teachers with a relevant post A-level qualification, but that there is 'only limited evidence of the impact of teachers' qualifications in the subjects they teach on pupil outcomes'.

It is here that the authors of the report get themselves tied up in knots. This is because they struggle to, first, come up with a suitable measure of subject knowledge and second, link this to student outcomes. For instance, in measuring subject knowledge they decide that a degree or other post A-level qualifications in a subject offers a proxy measure, but note that it is possible that teachers who have been defined as 'non-specialists' may have equal or greater subject knowledge acquired through other means than a degree, or through a degree with some overlapping subject content. This is an admission that, in practice, the report's writers were not able to strictly compare 'specialists' with 'non-specialists'. Then, the report concedes that it is "not technically possible to directly link data on teachers to pupil outcomes", which makes it difficult to offer an accurate assessment of the relationship between teacher characteristics and pupil outcomes.

Given these difficulties and limitations, it is tempting to ask why the report was written at all. It would perhaps not matter if this was simply one report. However, it is representative of a style of thought which dominates curricular and educational planning and is directly a product of modern technocracies. Its terms derive from the coarsest form of utilitarianism - it defines practical objectives and attempts to measure them. It seeks to reduce a complex set of relationships and practices to proxy measures of value-added and seeks to present itself as above ideology - indeed it represents a kind of 'end of ideology' argument where it is assumed that educational management simply involves questions of means and efficiency.

The logic of this argument is to try to convince readers that there is little measureable evidence that teachers who have made it their lifetime endeavour to 'persevere with geography', and who have viewed it as their mission to 
communicate the subject, enthuse and impart the wisdom of ages are in any sense preferable to or more effective at getting students to jump through the hoops required to gain educational credentials than a generalist trained in the techniques of classroom management and course delivery. The logical outcome of the report would lead to the practical policy that, as Fred Inglis (1975) once put it: 'Stupid people must be able to take over from clever ones'.

A slightly more subtle version of this type of approach to educational thinking is found in the Sutton Trust's report 'What makes great teaching?' (Coe et al., 2014), which is a review of the evidence relating to teacher effectiveness. This report is, at first glance, eminently sensible; it attempts to set out a comprehensive account of the factors that are known to contribute to 'great' teaching. One of its major limitations, though, is the way that a teacher's level of subject knowledge and expertise, including their ability to construct meaningful and worthwhile curriculum experiences, receives virtually no mention. The closest we get is the authors' revelation that 'the most effective teachers have deep knowledge of the subjects they teach, and when teachers' knowledge falls below a certain level it is a significant impediment to students' learning' (Coe et al., 2014: 2).

The important part of this statement is 'below a certain level'. Just what level is it that has to be maintained? Are we expecting teachers to be at the 'clever' or 'stupid' end of the knowledge continuum? The answer becomes clearer when the review cites research by Rockoff et al. (2011) to the effect that the relationship between a teacher's subject knowledge and pupil achievement is not a simple linear one. This is in line with Muijs and Reynolds' (2011) finding that increasing the subject knowledge of teachers is subject to a 'law of diminishing returns' and Hattie's (2008: 248) claim in Visible Learning a book reviewed by the Times Educational Supplement as 'the holy grail of teaching - that there is 'no preponderance of evidence to support the importance of subject or PCK'.

It is clear that those who argue for the importance of teachers as intellectuals, with a deepening and widening knowledge of their subject, are swimming against the tide of current educational opinion. True: no one is disputing that teachers' matter. Thus, in the aftermath of Hanushek's (1992) research, which suggested that the quality of a teacher can make the difference to a full year's learning growth, there has emerged a flourishing industry in research attempting to quantify this growth, using ever more sophisticated statistical measures of teacher effects (for a 'state of the art' review, see Muijs et al., 2015). We are now aware that not only does teacher quality remain the most important 'in school' variable, but that the variation of teacher quality is great. What is more, the relationship between simple measureable factors such as teacher credentials and teacher quality are unreliable. The search is on for generic theories of teacher effectiveness. Goldhaber (2008) uses a definition of teacher quality as a teacher's value added contribution to producing measurable gains for students in standardized exams. This is an example of using an educational production approach, one that 'is fundamentally concerned with the quantity 
and quality of educational outcomes that result from a given investment of resources' (Rice and Schwartz, 2008: 132).

What is remarkable about this discussion about teacher effectiveness and how to measure whether a teacher's subject knowledge has measurable 'impact' on students' achievement is that as little as thirty years ago it would have been unimaginable. This represents an historic shift how society sees the teacher's role (in 1969, Musgrove could introduce his study of teachers' work by commenting on the fact that teachers had been granted almost ultimate power to shape educational decision-making!) One of the most important consequences of this shift is that it has become increasingly difficult for geography teachers to understand their work as characterised by a long-lasting and enduring engagement with the discipline and an open-ended investigation of its educational potential for young people in schools. However, all is not lost: in recent years, this argument about the importance of geography has been expressed in the concepts of the 'geographical imagination' or 'thinking geographically' (Massey, 2014). In the rest of this article I hope to suggest how that important intellectual 'project' might be rekindled.

\section{Thinking geographically about Brexit}

This section considers the types of knowledge and understanding a geography teacher would require to help students begin to 'think geographically' about an event such as the United Kingdom's decision to remain in or leave the European Union. This is not a purely hypothetical example, since surely many geography teachers were faced with the challenge of teaching an impromptu lesson on this on the days following $23^{\text {rd }}$ June 2016. One solution to this, of course, and one that is presumably the logical endpoint of the report on subject specialism, would be to say that this is not 'on the syllabus' and that it would have little measurable impact on students' learning outcomes (in fact, the logical extension of that argument would be that a teacher who deviated from the 'syllabus' to deal with 'Brexit' is effectively doing their students a disservice!)

The starting point for any work in classrooms might be the immediate issue of the Brexit referendum, and a consideration of the map of voting patterns which showed distinct spatial patterns. On a turnout of $62 \%$ of those who were eligible to vote, $52 \%$ voted to leave, and $48 \%$ to remain. The result caused immediate turmoil: the British Prime Minister (who had called the referendum and campaigned to 'remain') stated his intention to resign once a new leader had been appointed, and the leader of the opposition party faced a vote of no confidence from MPs in his own party. It soon became clear that there had been no plan as to what would happen next - other than for Parliament to trigger Article 50 of the Treaty of Rome - and what the practical and legal arrangements of 'Brexit' would be. It was not clear whether parliament had to accept the decision as binding, or whether it could seek to overturn the will of the people. It was clear that what happened next was not simply a UK affair though, and much depended on the reaction of European politicians, some 
of whom indicated that it was imperative that the UK left as soon as possible, whilst others considered that there was bound to be a period of transition. ${ }^{3}$

These events are inexplicable without some understanding of the political geography of the European Union, and in particular the different phases of European integration (here, a series of political maps of Europe at particular times would be indispensable). So, having dealt with some of the 'preliminaries', the geography teacher would need to be able to explain something of the origins of the European Union. This does not require getting into dry discussions of the 'pillars' of the European Union - falling into a technocratic and limiting form of political education or 'civics'. Instead, a geographical approach would convey that the European Union has its origins in the aftermath of World War II, which itself can be seen as a culmination of almost half a century of political instability on the continent. In much of Western Europe, a settlement between capital and labour gave rise to period of economic stability and growth - the Golden Age or as the French call it, 'Le Trente Glorieuse' - and the evolution of welfare states which broadly reflected the view that governments' role is to provide social security, education, health care and social planning. The continued expansion of the European economy relied on coal and energy sources, and there was seen to be an advantage in co-operating to secure efficient and reliable reserves, leading to the establishment of the European Coal and Steel Community (ECSC) and Euratom. The Treaty of Rome, signed in 1958, called for 'ever closer union' between the 6 original signatories (France, Germany, Belgium, Netherlands, Luxembourg and Italy).

Having set out some of the background and context for the emergence of 'Europe' as an ideal and its practical arrangements, the geography teacher might help students to understand some of the tensions and contractions underpinning European economic and political geography. The European Union was a product of economic growth and expansion (an interesting, and unresolved, question is whether political union actually promoted growth, or whether it succeeded because of the fact of economic expansion). However, the European project had clear limits; most people in Europe saw their primary allegiance to the nationstate, and ideas about a European Defence Army never got off the ground. There was an expansion of the 6 to 9, with the UK, Denmark and Ireland by 1973 (as an aside, the UK's entry was more to do with its own failing economy at home rather than any commitment to Europe, but was widely accepted, with levels of support being higher in England than in Scotland and Wales).

Of course, this story would make little sense without some acknowledgement and understanding of the trajectories of the states of Eastern Europe, and the communist alternative that, for a time, seemed able to compete as

3. As the final version of this paper was prepared, the situation is, if anything, more confused than ever! The UK faces the prospect of embarking on talks about the proposed 'Brexit' without a majority government, with a general election in June 2017 removing the conservative government's majority in the House of Commons, leading The Economist newspaper to refer to London as 'Chaos-upon-Thames'. 
a model for economic development (in the early 1970s, for example, it was widely touted that East Germany [the GDR] scored higher in terms of overall quality of life than the UK). This becomes an increasingly important part of understanding the issue of Brexit.

Bickerton (2016) notes that by the mid-1970s it was assumed that European integration had run its course. However, in the 1980s the project enjoyed a revival. In the face of lower rates of economic growth and industrial restructuring, European governments found it difficult to resolve their domestic economic issues, and inflation and unemployment were running high. In this context, European co-operation appeared to offer a solution. A widespread shift in economic orthodoxy led governments to accept that growth could only be rebooted through the integration and expansion of markets. The parties of the left saw the possibility of the building of a 'social Europe', and the collapse of dictatorships in Greece, Spain and Portugal in the 1970s meant that European integration was seen as a means of bolstering democracy. The establishment of the single market was about restarting growth.

The Maastricht Treaty (signed in 1992) was a response to the changes that were taking place in Europe as a result of the collapse of communism and the break-up of the Soviet Union. The prospect of a united Germany led to political concerns and for Britain and France the Treaty was a way of binding Germany to a set of rules. But crucially its impact was on economics, especially the idea of the European Monetary Union, which required currency convergence and that all member states adopted tough policies on spending and budget deficits. It was effectively a way of managing the new economic conditions and reducing expenditures.

To this geo-historical narrative must be added the theme of migration, which played such a central role in the lead up to Brexit. Until the mid-2000s labour mobility in Europe was low, with only 1 percent of total EU citizens living in an EU country other than their own. Migration after 1945 in Europe had been from non-European countries in order to solve the problem of insufficient labour supply. In the UK this was people from former colonies of the New Commonwealth and Pakistan, West Germany had its gastarbeiters (predominantly from Turkey) and France gained workers from its former links with North Africa. However, the situation has now changed, with 3 percent of EU citizens living in other EU countries.

Three factors explain this: the Schengen regulations which support free movement of EU citizens; the enlargement of the EU with the accession of 8 post-communist states in 2004 and Romania and Bulgaria in 2007; and the financial crisis after 2007-08 which has led to inter-state migration from Southern European nations such as Greece, Spain and Italy. The patterns of net gains and losses is predictable, with UK, Austria, Germany, Sweden and Belgium and Ireland all attracting migrants, and 'transition' economies such as Poland, Bulgaria and Slovakia supplying them.

There are lots of issues that political geographers need to understand to make sense of these developments. One is to understand the nature of the 
European economy, which suggests that such a thing exists. In reality, the 'European Economy' is a series of national economies and this is inevitable, given that national governments account for 40-50 percent of spending. Despite integration, national borders remain. Much movement and differences between member states relate to their own patterns of development, with unemployment rates, flows of migration and rates of economic growth varying across Europe. Some governments run deficits on their budgets and others surpluses. There are also varying approaches to welfare provision, with benefits and entitlements varying across the member states. In addition, it is hard to think of a European culture beyond the annual Eurovision contest which now includes, bizarrely, Australia - and football.

This is, of course, a complex set of issues, and teaching about Brexit is a challenge. Geography teachers have to struggle to make sense of this for themselves, to think carefully about how the discipline helps them to frame and analyse the events, to keep abreast of current coverage and to make judicious choices about what to read. All this before they make 'practical' decisions about how to represent the issue, in what sort of depth, using what resources and strategies. But this, I would argue, is what it means to 'persevere with geography' and given Inglis' comment about wanting to replace clever people with stupid people, the question is how to ensure a quality supply of 'clever' geography teachers; teachers who are able to 'persevere with their geography' so as to acquire the knowledge and understanding, as well as the teaching skills to help young people take part in the type of 'complicated conversation' such as that surrounding Brexit? This requires a principled and rigorous approach to the training of geography teachers. The next section reviews how this has developed in recent decades.

\section{Towards a theory of geography teaching}

In this section I want to outline the development of approaches to the initial training of geography teachers. My focus is on the English case, but, as Whitty (2014) has intimated, this is a part of a wider trajectory in English-speaking countries. I suggest that there have been a number of phases and these, of course, related to wider shifts and developments within teacher education and within the academic discipline. A number of commentators have remarked on the gradual shift away from concerns of curriculum content to a focus on pedagogy. However, there has been little written about how this has come about. ${ }^{4}$

\section{The quiet half century}

In Making Human Geography (2012), Cox suggests that it is helpful to divide the twentieth century into two halves, what he calls the 'quiet half century' from 1900 to 1950 and 'modern' geography. The quiet half century was char-

4. This section is based on Morgan (2018). 
acterised by an empirical and descriptive form of geographical knowledge. It was this period that saw the development of school geography, which was closely linked to the development of the wider discipline. Indeed, in England the university subject developed on the basis that it would provide a ready supply of geography 'masters' to teach the subject in schools. School geography was a simplified version of the subject as studied and taught in universities, with an emphasis on the description and classification of the places and regions of the world. This gave rise to the classic stereotype of the male geography teacher, covered in chalk dust, relaying volumes of facts about trade winds and trade statistics. Teaching was 'traditional', relying on the transmission of large amounts of factual knowledge.

\section{Modern school geography}

Things changed after the Second World War. Modern school geography was a product of the post-war expansion of schooling in the second half of the twentieth century. By the mid-1950s, geography was in a strong position in schools, and a period of university expansion served it well, since it was widely accepted that a better educated workforce was required to achieve economic success and that this demanded more qualified and better teachers. Teaching should be a degree-based profession and teacher training was provided in university departments of education.

The impetus for this was the growing interest in educational psychology and the rise of curriculum development and planning. This period saw the publication of the 'canonical' texts of modern geography education - Norman Graves' (1975) Geography and Education, Bill Marsden's (1976) Evaluating the Geography Curriculum and David Hall's (1976) Geography and the Geography Teacher. These contributed to ongoing work on curriculum development in the form of a series of government-backed curriculum development projects. These projects drew upon developments in educational theory and the paradigm shift that was taking place in geography as a discipline. This period of educational modernisation effectively changed what it meant to be a geography teacher. The aims, contents and methods of teaching were all changed, amounting to a new professionalism.

\section{Critiques of schooling}

Looking back, it is clear that the optimism of this period came under close scrutiny in the 1970s and 1980s. One source of this came in the form of a radical critique of schooling as an institution, symbolised by the popularity of a series of 'Penguin Specials' with titles such Compulsory miseducation (Goodman, 1962), School is dead (Reimer, 1971), and most famously, Deschooling Society (Illich, 1970) and Teaching as a subversive activity (Postman and Weingarter, 1969). These books challenged the assumption - widely held in the post war decades - that more schooling was necessarily a 'good' thing. 
Although geography education was not at the leading edge of these developments (its key figures were aligned to the technocratic modes of curriculum planning and evaluation, the positivist tradition of the new geography), its liberal humanist traditions ensured that teacher education was receptive to the more open pedagogies associated with these movements, and eventually the more humanistic and radical approaches began to influence school geography. A series of 'ideology critiques' challenged the political bias in dominant versions of school geography (e.g. Gilbert, 1984). This perceived shift to the political left spawned a reaction in the form of the New Right, which sought to develop a national curriculum and challenge what it saw as the practices of teacher educators who were dubbed 'the wayward elite' (O'Keefe, 1985). This was part of an international trend towards centralised curricula. Teacher education was also subject to change: from the early 1980s governments sought to gain central control over the training and development of teachers. University courses of teacher training required approval, which meant that aspects of the content and delivery of teacher education were in the hands of an external agency. These courses were held accountable through an inspection regime. The general move has been to define the amount of time that is spent on generic or professional studies as opposed to subject-based time, and also to shift the balance towards more time spent in schools. One of the effects of these changes has been to ensure that the geography component of teacher training meets with external requirements for wider goals such as literacy or teaching with technology.

\section{The end of teacher education?}

These developments have led to important changes in the training and preparation of geography teachers. At present, geography teacher education is assailed from all sides. On the one hand it is subject to moves to increase the level of school-based training for geography teachers. Whilst in principle this is no bad thing, in reality, schools increasingly operate within an environment defined by external definitions of what is important and the past two decades have seen a growing move towards genericism - with strategies of teaching and learning taking more of a central role than the what of teaching or curriculum. Teacher education courses themselves have been subject to inspection and external definition of what they should contain, and this reflects the 'therapy culture' that shapes discussion of schooling Hayes, 2017). At the same time, geographers working in universities have experienced the pressure of research assessment exercises which focus on specialised studies rather than more general geographical approaches, the effect of various 'theoretical turns' has widened the gap between the subject as taught and studied in universities and schools.

In 1972, David Harvey remarked that, 'I have always thought that the job of the teaching college geographer is to grapple with theory in all its complexity'. The question, as always, is what type of theory. But it is possible to argue that current models of geography teacher education are more concerned with 
'learning theory' and the socialisation functions of education than with enabling teachers to understand the complexities of geographical knowledge and its transmission. In the final section of this article, I provide a sketch of how geography educators might return to these questions.

\section{The right kind of geography?}

In recent years, largely prompted by the interventions of the sociologist of education Michael Young, there has been an important development in discussions about school geography. Young was an important figure in the 1970s sociology of education, not least because of his publication Knowledge and Control which argued that school knowledge was not a neutral, politically innocent body of knowledge to be transmitted to the next generation but instead reflected the interests and world-views of the powerful (Young, 1971). Though influential figures such as Graves, Hall and Marsden did not accept this sociological view of curriculum, in the 1980s there were important critiques of how school geography served to support the status quo, and the view of geographical knowledge as 'relative' became commonplace. Thus, Young's volte face, symbolised in his 2008 book Bringing Knowledge Back In, was highly significant (for a set of reflections on Young's long career, see Guile et al., 2018). It has spawned important discussions in geography education. Young's position is that the curriculum should reflect a 'social realist' view of knowledge. Briefly stated, this social realism recognises that all knowledge is 'socially produced', but this does not mean that it is indelibly shaped by its 'social location'. Knowledge transcends the conditions of its production and exists independently (see Morgan et al., 2018 for an account of the origins and development of social realist perspectives). To give a geographical example, Walter Christaller's 'central place theory' was produced whilst Christaller was a member of the German National Socialist Party and sought to show what a rational settlement pattern might entail once Poland had been returned to Germany. Despite its unsavoury origins, this does not mean that Christaller's ideas are without merit or should not be taught. His $\mathrm{K}=3$ principle is still powerful, and worthy of empirical testing and theoretical reflection.

The focus, Young insists, should be on providing all students with powerful knowledge, and the curriculum challenge is to identify the types of knowledge to make up the curriculum. To this end, Young and Lambert's (2015) Knowledge and the Future School sets out to distinguish between different versions of school knowledge.

The argument has long been made that a focus on subject knowledge risks the reification of static forms of out-moded and irrelevant knowledge. In geography, a constructivist epistemology is associated with progressivism. Thus, as early as the 1960s there was an identification towards the learner-centred and community-centred curriculum. However there is no reason why a subject-centred approach should not at the same time be both relevant, responsive to changes in the discipline and 'actually existing 
geography', and offer students the type of 'powerful knowledge' required to find their way in a complex society.

In order to illustrate what I have in mind I will finish this article with an example of how geography teacher educators could work with beginning teachers to develop this type of discipline based powerful knowledge. My example is political geography, a part of the discipline about which, in my experience, few graduate geographers who are about to become geography teachers have much knowledge and expertise but which, as the Brexit example suggests, is central to understand aspects of the contemporary world.

Now, a glance at the daily newspaper or newsfeed reminds us that it is difficult to think about the geography of the contemporary world without encountering aspects of political geography (though it is interesting how the advent of social media as news sources changes flows of information). Clearly, there is a bewildering range of issues and events, and in order to teach aspects of political geography, teachers need a broad geo-historical understanding through which to make sense of a changing world. Such a narrative might include the rise of sugar and spice trades, the subsequent colonisation of Africa by European powers leading to the partition of the continent at the Berlin conference of 1884-85, the period of world conflict between 1914 and 1945 , the rise of the Cold war and superpower politics, critiques of Western models of development and the era of African independence, the collapse of communism and the so-called 'End of History', the rise of China, India and the war on terror following $9 / 11$.

As well as possessing a broad geo-historical map of the changing political geography, it is important that teachers understand how geography as a discipline and political geography as a sub-discipline have developed in response to this changing geo-historical narrative. They need to be able to recognise that political geography was associated with the advent of geopolitics in the late $19^{\text {th }}$ century, where figures such as Mackinder and Ratzel proposed geographical accounts of the world that favoured the interests of their own states. Unsurprisingly, in the second half of the twentieth century, political geography went into a period of decline in which it reverted to a descriptive discipline concerned with the shape of states or the geographical nature of boundaries. It was not until the 1960s and 1970s, in the face of the growing unrest in large cities, the student demonstrations around Vietnam and the emergence of radical geography, that political geography regained its relevance and potency, to the point where it is concerned with 'the politics in geography'.

Armed with these frameworks, teachers would be able to identify and utilise in their planning - in the short-term, medium and long-run - a series of approximately 15-20 concepts that emerge from their understanding of the narrative and the discipline (for what it's worth, my starting list is shown in Table 1). Teachers should grasp that these concepts are not a list of content to be taught, but are ideas to think with. They are unstable in the sense that they are being discussed and refined at the academic frontiers of the discipline, and they are tested in the light of changing geopolitical realities. Think for 
Table 1. Political geography concepts

\begin{tabular}{ll}
\hline State & Welfare State \\
Territory & Political system \\
Border/Boundary & World Systems Theory \\
Nation & Geopolitics \\
Nationalism & Colonialism \\
Sovereignty & Post-colonialism \\
Participation & Regionalism/localism \\
Election & Power \\
Citizenship & \\
\hline
\end{tabular}

Source: author.

example, of the concept of citizenship, for which it is generally agreed that there is no clear definition, but as a concept changes in relations to the social processes of state formation.

Finally, with all this in place, teachers need to be able to make judicious choices about the examples and case studies they will develop in their units of work. Obviously, the possibilities here are endless, so there has to be some disciplined thinking behind the selection. It is possible to suggest that case studies might be chosen on the basis that they are of enduring importance and because they reflect what we might hope any educated young person to 'know' about. Examples might include the Israel-Palestine conflict that has marked the post-war years, or the rise and fall of apartheid in South Africa. In addition, selection might be made on the basis that case studies illustrate a range of 'concepts' that are essential to understanding the discipline. Or again, there are times when 'topicality' or 'relevance' are justification for teaching an example, for instance the Olympic Games provide a useful context for teaching about important aspects of geopolitics.

If all this is taught well in teacher education courses, and with levels of discussion that lead to inevitable questions about curriculum making in its widest sense (including practical issues about resources and how best to 'get concepts across'), then it is probably the case that there will not be much (any?) time left over to deal with 'learning theory'. This need not matter. This is an approach to geography education that is unashamedly 'knowledge-led' rather than 'knower-led'.

\section{Conclusion}

It is clear that teachers matter. If there was ever a 'golden age' for teacher education it is now past. Governments see investment in education as central to bolstering economic growth, and teacher quality is a variable that they seek to control. To seek to improve the supply of 'more better teachers' is a legitimate concern, and the literature discussed at the start of this article is indicative of this. However, it is also legitimate to question the limited parameters of 
this 'production' view of teaching. In this article I have argued that if we are concerned with the quality of geographical thinking among future generations, it would be best to recruit to the profession specialist geography teachers (i.e. those who have studied the subject in depth), develop programmes of teacher education that are rich in knowledge and provide a conceptual framework for the curriculum planning, and which, above all, encourage teachers to 'persevere with their geography' so as to see their role as contributing to the creation of an educated citizenry.

\section{Bibliographical references}

BeLL, D. (2016). "I Persevered with My Geography". South Atlantic Quarterly, 115, 685-697. <https://doi.org/10.1215/00382876-3656092>

Bickerton, C. (2016). The European Union: A Citizen's Guide. London: Penguin.

Coe, R., Aloisi, C., Higgins, S., and Elliot Major, L. (2014). What makes 'great' teaching? A review of the underpinning research. London: The Sutton Trust.

Cox, K. (2012). Making Human Geography. New York: Guilford Press.

DEPARTMENT FOR EDUCATION (2016). 'Specialist' and 'non-specialist' teaching in England: Extent and impact on pupil outcomes. London: Department of Education.

GILBERT, R. (1984). The Impotent Image: Reflections of Ideology in the Secondary School Curriculum. Lewes: The Falmer Press.

Goodman, P. (1962/1971). Compulsory Miseducation. Harmondsworth: Penguin.

GOLDHABER, D. (2008). "Teachers matter, but effective teacher quality policies are elusive". In: H. Ladd and E. Fiske (eds.). Handbook of Research In Education Finance and Policy. London: Routledge.

Graves, N. (1975). Geography and Education. London: Heinneman.

Guile, D., Lambert, D., and Reiss, M. (eds.) (2018). Sociology, Curriculum Studies and Professional Knowledge: New Perspectives on the Work of Michael Young. London: Routledge.

Hall, D. (1976). Geography and the Geography Teacher. London: George Allen and Unwin.

Hall, S. (2008). “An interview with Stuart Hall, December 2007. By Colin MacCabe". Critical Quarterly, 50 (1-2), 12-42.

HANUSHEK, E. A. (1992). "The trade-off between child quantity and quality". Journal of Political Economy, 100 (1), 84-117. <https://doi.org/10.1086/261808>

Hattie, J. (2008). Visible Learning. London: Routledge.

HAYES, D. (2017). "Seven ways education needs to change in 2017. The Conversation". Downloaded from: <https://theconversation.com/seven-ways-educationneeds-to-change-in-2017-70821> (last accessed 28 February 2017).

ILLICH, I. (1970/1973). Deschooling Society. Harmondsworth: Penguin.

InGLIS, F. (1975). Ideology and the Imagination. Cambridge: Cambridge University Press.

Marsden, W. (1976). Evaluating the Geography Curriculum. Edinburgh: Oliver and Boyd.

MASSEY, D. (2014). "Taking on the World". Geography: An International Journal, 99 (1), 36-39. 
Morgan, J., Hoadley, U., and Barrett, B. (2018). "Introduction: social realist perspectives on knowledge, curriculum and equity”. In: B. BARRETT, U. HOADLEY and J. Morgan (eds.) Knowledge, Curriculum, Equity: Social Realist Perspectives. London: Routledge, 1-16.

Muijs, D. and ReYNOLDS, D. (2011). Effective Teaching: Evidence and Practice $\left(3^{\text {rd }}\right.$ Edition). London: Sage.

Muijs, D., Reynolds, D. and KyriaKides (2015). "The scientific properties of teacher effects/effective teaching processes”. In: The Routledge International Handbook of Educational Effectiveness and Improvement. London: Routledge.

Musgrove, F. (1969). Society and the Teacher's Role. London: Routledge Kegan and Paul.

O'KeEfe, D. (1985). The Wayward Elite. London: Institute of Economic Affairs.

Postman, N. and Weingarter (1969/1971) Teaching as a Subversive Activity. Harmondsworth: Penguin.

ReImer, E. (1971). School is Dead: An Essay on Alternatives in Education. Harmondsworth: Penguin.

RICE, J-K. and SCHWARTZ, A. (2008). "Towards an understanding of productivity in education". In: H. LADD and E. FISKE (eds.) Handbook of Research in Education Finance and Policy. London: Routledge.

Rockoff, J. E., Jacob, B. A., Kane, T. J., and Staiger, D. O. (2011). "Can you recognize an effective teacher when you recruit one?” Education, 6 (1), 43-74. $<$ https://doi.org/10.1162/edfp_a_00022>

WhitTy, G. (2014). "Recent developments in teacher training and their implications for the "University project' in education". Oxford Review of Education, 40 (4), 466-481. <https://doi.org/10.1080/03054985.2014.933007>

Young, M. (ed.) (1971). Knowledge and Control: New Directions in the Sociology of Education. London: Collier-Macmillan.

Young, M. (2008). Bringing Knowledge Back In: From Social Constructivism to Social Realism in the Sociology of Education. London: Routledge.

Young, M. and LAmberT, D. (with C. Roberts and M. Roberts). (2015). Knowledge and the Future School. London: Bloomsbury. 